\title{
The Art of Shaping Defense Policy: Scope, Components, Relationships (but no Algorithms)
}

\author{
Todor Tagarev ${ }^{*}$
}

In 1999-2000, I taught the first defense planning course at the "G.S. Rakovski" Defense and Staff College in Sofia, Bulgaria. All students were senior officers-mostly full colonels - and yet the course had to begin with a thorough explanation of what "defense planning" is and how it differs from and relates to "operational planning." At the time, references to "planning" in regard to the military almost exclusively addressed the intended use of available forces, or what was known as "strategic and operational planning." That is hardly surprising, because - unlike in NATO - defense policy-making and planning in the Warsaw Pact were fully centralized. The capitals, with the exception of Moscow, had either no or very limited knowledge and experience in defense policy and planning.

In addition, in the 1990s the defense establishments in the former Warsaw Pact countries and ex-Soviet republics were only a small part of what were immature and generally weak democratic institutions. Even under the impact of declining economies and the lack of an obvious enemy, senior political and military leaders felt safer adhering to inherited force structures and force development models. One result is that, at the time of their accession, very few of the new NATO members had any sizeable contribution to make to the Alliance's capabilities. ${ }^{1}$

A reader who is an experienced defense policy maker or defense planner is advised to skip this article. But many defense establishments in Partner countries, as well as in a number of new NATO members, still struggle with the concept of defense policy, the role of civilians in defense, the concept of capability, the linkage between plans and budgets, and the relationship between force development and technological modernization.

This article is intended to facilitate an understanding of basic concepts and relationships in defense policy making. It does not provide an algorithm, nor any one-size-fitsall templates of processes and documents. The figures included in this article are intended to illustrate relationships, and not algorithmic steps. Nevertheless, I hope that it

\footnotetext{
Dr. Todor Tagarev is Associate Professor at the "G.S. Rakovski" Defense and Staff College in Sofia, Bulgaria, and chairs its Defense and Force Management Department. Former Director for Defense Planning in Bulgaria's Ministry of Defense, Dr. Tagarev is currently involved in a number of PAP-DIB activities - primarily in Ukraine, Moldova, and Georgiaconducted by the Geneva Centre for the Democratic Control of Armed Forces (DCAF); the Centre for European Security Studies (CESS), Groningen, The Netherlands; and the Center for Civil-Military Relations (CCMR) at the U.S. Naval Postgraduate School in Monterey. The opinions expressed herein are those of the author and are not necessarily shared by Bulgaria's government or any of the other listed organizations.

1 See, for example, Jeffrey Simon, "The New NATO Members: Will They Contribute?" Strategic Forum 160 (Washington, D.C.: National Defense University, April 1999), available at http://www.ndu.edu/inss/strforum/SF160/forum160.html.
} 
might assist readers who are interested in the art of defense policy-making in assessing weaknesses and identifying opportunities for improvements in the process of articulating defense policy, supported by planning and force structure development and all balanced by the risks posed to even the best-laid defense plans by changes in the funding environment.

\section{Why the Interest in Defense in the Twenty-First Century?}

$$
\begin{aligned}
& \text { You may not be interested in war, but war is interested in } \\
& \text { you. } \\
& \text { - Leon Trotsky }{ }^{2}
\end{aligned}
$$

This quote from Leon Trotsky eloquently summarizes the reasons behind the widespread public interest in defense issues in the new century. But why is the discussion on defense and defense policy so important at a time when most states in Europe and North America do not feel threatened by acts of armed aggression launched by other states against their territories?

It may be that war as we know it from the experience of two world wars of the twentieth century is not on the global security agenda in the foreseeable future, but at the same time,

... in the Balkans, Africa, the Caucasus, and Moldova, but especially in Iraq and the Middle East, crises remain unresolved, wars are still going on and chaos could spread, while international terrorists have already proved that they are capable of striking everywhere and destabilizing the traditional patterns of international security. Whether they like it or not, whether they are ready or not, Europeans will not be able to avoid this international disorder, at a time when security has become a major concern of European citizens. ${ }^{3}$

\section{What is "Defense Policy"?}

Neither NATO's Glossary of Terms and Definitions ${ }^{4}$ nor the U.S. Department of Defense's Dictionary of Military and Associated Terms ${ }^{5}$ propose a definition of defense

2 No source of this quote has been clearly identified, but it is commonly attributed to Leon Trotsky. See http://en.wikiquote.org/wiki/Leon_Trotsky.

3 European Defense: A Proposal for a White Paper, Report of an independent Task Force (Paris: EU Institute for Security Studies, May 2004), 5; available at www.iss-eu.org/ chaillot/wp2004.pdf. NATO Glossary of Terms and Definitions, NATO Standardization Agreements, AAP-6, 2005; available at http://www.nato.int/docu/stanag/aap006/aap6.htm.

5 Department of Defense Dictionary of Military and Associated Terms, Joint Publication 1-02 (Washington, D.C.: Department of Defense, 12 April 2001, as amended through 31 August 2005), available at www.dtic.mil/doctrine/jel/new_pubs/jp1_02.pdf. 
policy or policy. Among the various authoritative definitions of policy, the following two in the Webster's Dictionary are appropriate for our discourse: ${ }^{6}$

1. A definite course or method of action selected from among alternatives and in light of given conditions to guide and determine present and future decisions

2. A high level overall plan embracing the general goals and acceptable procedures esp. of a governmental body

The on-line portal Armchair Generalist provides a definition that is in line with the first of the Webster's definitions listed above. ${ }^{7}$ Paraphrasing to avoid the U.S.-oriented specifics of the definition, defense policy is

a course of action or conduct, as defined by senior executive leadership, intended to influence and determine decisions, actions, and other matters relating to the conduct of military affairs, consistent with the [nation's] security strategy. ${ }^{8}$

In line with the second Webster's definition, a number of on-line dictionaries define defense policy as "a program for defending a country against its enemies," where program is further defined as "a system of projects or services intended to meet a public need." $"$

\section{Thesis}

The two definitions given above do not contradict each other; rather, they are complementary. A good starting point in a discussion on defense policy is to clarify that the term defense policy covers both ends - that is, what needs to be achieved-as well as ways and means - how and with what resources those ends are to be achieved.

In regard to policy as it relates to defense and military matters, there are two distinct tasks:

1. How to use available means to reach the ends, e.g., in the event of military aggression against a country

2. Define the means that would allow a nation to deal effectively with likely future threats and challenges

6 Webster's Ninth New Collegiate Dictionary (Springfield, MA: Merriam Webster Inc., 1991); emphasis added.

7 "Defense Policy Versus Strategy and Tactics," at http://armchairgeneralist.typepad.com/ my_weblog/2004/12/1_defense_polic.html (viewed 14 March 2006).

8 Security strategy may refer to the strategy of a nation, as well as to that of an alliance.

9 See, for example, The Free Dictionary (http://www.thefreedictionary.com/defence+policy); Dictionary.LaborLawTalk.com (http://dictionary.laborlawtalk.com/defence_policy); Die.net (http://dict.die.net/defence\%20policy/); WorldWeb Online (www.wordwebonline.com/en/ defencepolicy); Answers.com (www.answers.com/topic/defense-program-defense-policydefence-program-defence-policy); and eLook.org (http://www.elook.org/dictionary/defencepolicy.html). 
The first task encompasses issues from both the strategic and operational realms, including both deliberate and contingency planning, as well as direction of troops in combat. It is often referred to as force employment.

The second task is the primary task of defense policy, and is the focus of this essay. It can be approached in a variety of ways. In goal-oriented (or "top-down") approaches, desired ends drive the design of future forces, which is illustrated in Figure $1 .^{10}$ For instance, defense transformation would hardly be possible if policy and planning are not "goal-oriented."

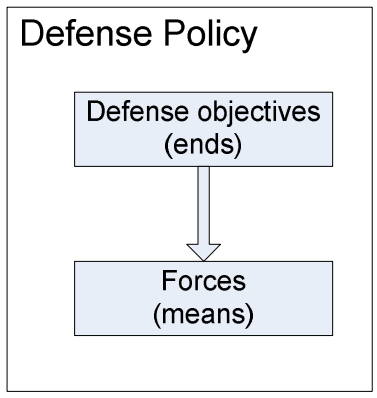

Figure 1: Relations between Ends and Means in Devising Defense Policy

Although it will be obvious to many readers, the premise that defense policy requires the definition of both ends and means is not easily understood and readily accepted everywhere, in particular in countries in the post-Soviet space. One reason is language. ${ }^{11}$ In a number of languages — quite possibly in all Slavic languages - there is only one word, politika, that is used to translate both policy and politics; this word has strong connotations of everything "political."12 Therefore, a quite common perception is that defense policy resides in the realm of the politicians, but the term is understood narrowly as including only making decisions on the ends-i.e., setting the objectives that the armed forces must be able to attain.

10 For other approaches and a discussion of the advantages and disadvantages of this approach, refer to Henry Bartlett, G. Paul Holman, and Timothy E. Somes, "The Art of Strategy and Force Planning," in Strategy and Force Planning, eds. R. M. Lloyd, et al. (Newport, RI: Naval War College Press, 1995), 15-27; and Handbook on Long Term Defence Planning, RTO Technical Report 69 (Paris: NATO Research and Technology Organization, April 2003), available at http://www.rta.nato.int/Pubs/RDP.asp?RDP=RTO-TR-069.

11 It is certainly not the most important one, however. Lack of civilian expertise, prevalent patterns of civil-military relations, and cultures of secrecy, among others, also contribute to opacity and inefficiency of defense policies, planning, and plans. See Daniel Nelson, "Beyond Defense Planning," in Transparency in Defense Policy, Military Budgeting and Procurement, ed. Todor Tagarev (Sofia: Geneva Centre for DCAF and "George C. MarshallBulgaria," 2002).

12 As far as I am aware, this is also the case in the Romance languages (politique, politica). 
On the other hand, and given the often frequent lack of knowledge on military matters among politicians and their civilian staff in post-Soviet states, it is often taken for granted that only the military have the knowledge and the authority to define what forces are needed in order to meet their objectives - a process that is also understood as implementing the policy that has been determined by politicians. According to Soviet terminology, this is referred to as the "build-up" (stroitel'stvo) of the armed forces. In the post-Soviet era, this understanding is often disguised under the rubric of "military policy."

The main thesis of this essay is that defense policy encompasses both ends and means, and desired ends drive the creation of adequate means (forces). A number of amendments need to be made in order to make the representation on Figure 1 useful in practice.

\section{Amendment 1: Defining Defense Objectives}

The elaboration of defence policy flows from the desire to uphold and promote the values and the interests of a nation or an alliance, the underlying security strategy and the role of the military among the instruments of national power, all of which influence the definition of defense objectives (as shown in Figure 2). Defense objectives, in turn, are often expressed as defense missions, i.e. possible roles of the armed forces, and levels of ambition in defense.

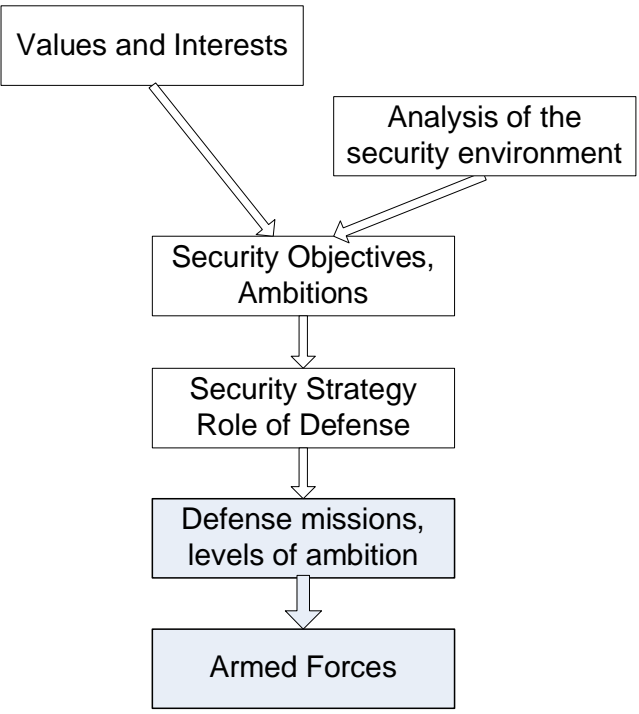

Figure 2: Definition of Defense Objectives 


\section{Analysis of the Security Environment}

Security objectives, strategies, and defense objectives stem from values, interests, and security challenges, risks, and threats that have been identified as a result of thorough analysis of the security environment. Current security analysis emphasizes threats posed by (among others):

- International terrorism

- Proliferation of weapons of mass destruction and the means for their delivery

- Failed or failing states

- Organized crime,

as well as a variety of combinations among them. Other risks originate from ethnic tensions and the failure to respect differing ethnic, religious, and cultural values; intolerance and xenophobia; demographic pressures; and environmental degradation.

Countries in transition see as a particular challenge the frequent lack of accountability on the part of the armed forces (and other security sector organizations) to civil society. Additional challenges include widespread inefficiency of the defense sector in transitional states; the preservation of large ineffective force structures; and a lack of management expertise to deal with a variety of legacy issues. For example, the countries from South Eastern Europe (SEE) in a "common assessment paper" identified as a particular challenge the "failure of [defense] reform and disruptions in [Euro-Atlantic] integration processes [that] could result in negative consequences on regional and international security." 13

As a result of the analysis of the security environment, it is particularly important to state explicitly and clearly the general lack of risks and threats, especially of the kind that have until recently had a strong impact on defense policies. In the example of the South Eastern European assessment, the countries agreed that "there is no perceived risk of military aggression between states in SEE in the current and foreseeable political environment." 14

\section{Security Objectives}

The objectives of the security policy of a state address current and foreseeable security challenges, risks, and threats, and reflect the values and interests of the nation, as well as its ambitions in the international security arena. For example, the aim of the 2002 National Security Strategy of the United States is "to help make the world not just safer but better." In that light, it sets forth the following goals, or "security objectives": ${ }^{15}$

13 South East Europe Common Assessment Paper on Regional Security Challenges and Opportunities-SEECAP (Budapest, May 2001), para 16(g); available at www.nato.int/ docu/comm/2001/0105-bdp/d010530b.htm.

15 The National Security Strategy of the United States of America (Washington, D.C.: The White House, September 2002), 1; available at www.whitehouse.gov/nsc/nss.html. 
- Political and economic freedom

- Peaceful relations with other states

- Respect for human dignity

In addition, the National Defense Strategy of the United States provides the following definitions of four "strategic objectives" in terms of security and defense, all in line with the National Security Strategy: ${ }^{16}$

- Secure the Unites States from direct attack

- Secure strategic access and retain global freedom of action

- Strengthen alliances and partnerships

- Establish favorable security conditions

\section{Security Strategy}

A good security strategy provides a clear, realistic, and effective concept of the use of diplomatic, economic, military, and other instruments of power in order to achieve a nation's security objectives. Depending on assessments of security risks and threats, potential opponents' traditional strengths and weaknesses, and identified opportunities - along with an assessment of one's own and one's adversaries' vulnerabilitiesthe security strategy may envision various roles for the armed forces among the instruments of power. These roles are often referred to as the "missions" of the armed forces.

\section{Defense Missions and Goals}

Bulgaria's 2002 White Paper on Defense defines the following missions of the nation's armed forces: ${ }^{17}$

- Contribution to national security in peacetime

- Contribution to peace and security in the world

- Participation in the defense of the country

Similarly, the United Kingdom defines its "defense aims" in the following manner:

To deliver security for the people of the United Kingdom and the Overseas Territories by defending them, including against terrorism; and to act as a force for good by strengthening international peace and stability.

In the U.S. example referred to above, the military is tasked to contribute to the accomplishment of the nation's security objectives in four main ways. (The title of the re-

16 The National Defense Strategy of the United States of America (Washington, D.C.: Department of Defense, March 2005), iv, details on 6-7; available at www.defenselink.mil/ news/Mar2005/d20050318nds1.pdf.

17 White Paper on Defense (Sofia: Ministry of Defense, 2002), 27; available at www.mod.bg/ $\mathrm{bg}$ /docs/BULWP.pdf. This document was adopted prior to NATO's invitation to Bulgaria to join the Alliance at the 2002 Prague Summit. 
spective section of the document underlines the role of defense as an instrument in the implementation of security policy; on the other hand, these may be interpreted as "defense objectives"): ${ }^{18}$

- Assure allies and friends

- Dissuade potential adversaries

- Deter aggression and counter coercion

- Defeat adversaries

\section{Defense Ambitions}

The "level of ambition" of a defense establishment sets forth in military terms the number, scale, and nature of operations that a country (or an alliance) should be able to conduct. ${ }^{19}$ A related term is operational tempo. It refers to the number and size of missions undertaken by a military force relative to its strength, and takes into account the complexity and the length of these operations. A high operational tempo indicates a significant number of sizeable, ongoing deployments to multiple theatres. ${ }^{20}$ For example, NATO's stated level of ambition is to be able to conduct three simultaneous major joint operations outside of the territory of the Alliance. ${ }^{21}$

The member states of the European Union have committed to be able by 2010

... to respond with rapid and decisive action applying a fully coherent approach to the whole spectrum of crisis management operations covered by the Treaty on the European Union. This includes humanitarian and rescue tasks, peace-keeping tasks, tasks of combat forces in crisis management, including peacemaking. As indicated by the European Security Strategy this might also include joint disarmament operations, the support for third countries in combating terrorism and security sector reform. ${ }^{22}$

Likewise, the level of ambition of a country is defined in military terms as the number, scale and nature of operations that it should be able to conduct on its own or as part of coalition or alliance.

18 The National Defense Strategy of the United States of America, iv, details on 7-9.

19 The Defense Planning Process [of NATO], available at www.nato.int/issues/dpp/index.html.

${ }^{20}$ Canada's International Policy Statement, A Role of Pride and Influence in the World: Defence (Ottawa: Minister of National Defence, 2005), 7.

21 See, for example, Michèle A. Flournoy, CSIS, "Defense Integration in Europe: Enhancing Europe's Defense Capabilities for New Missions," paper presented to the Clingendael Security and Conflict Program workshop Enhancing European Military Capabilities within the EU and NATO (The Hague, 14-15 December 2005), notes to slide 17; available at www.clingendael.nl/cscp/events/20051214/Flournoy.ppt (viewed 20 January 2006).

${ }^{22}$ Headline Goal 2010, approved by General Affairs and External Relations Council on 17 May 2004, endorsed by the European Council of 17 and 18 June 2004; available at http://ue.eu.int/uedocs/cmsUpload/2010\%20Headline\%20Goal.pdf; emphasis added. 
The U.K., in its current Defense White Paper, defines the following ambition levels: ${ }^{23}$

- Support three concurrent operations, of which one is an enduring peace support operation

- Conduct limited national operations

- Be the lead, or framework nation for coalition operations on a small to medium scale

- Retain the capacity to undertake large-scale operations at longer notice in Europe, the Mediterranean, and the Gulf region

The second and third of these ambitions lead to the requirement to maintain a broad spectrum of maritime, land, air, logistics, C4ISR, and special forces capability elements.

France, in its Program Law 2003-2008, also very clearly defines its defense ambitions, stating that the country must: ${ }^{24}$

- Protect [France's] autonomy of decision and action ..., including the ability to act alone should it be necessary (e.g., to ensure defense of sovereign territories and ... to meet her defense agreements in Africa and the Middle East)

- Have the capability of a lead nation in a European operation and sufficient military capabilities to contribute to a spectrum of military actions, especially in high-intensity operations

- Maintain the "necessary technological know-how to ensure, through time, the credibility of nuclear deterrence, to develop the resources of protection against new threats, and to preserve an industrial base ..." to manufacture her own major defense systems

The French Program Law also states that, in order to meet this level of ambition, France will increase its personnel levels, and therefore its defense spending. The law provides considerable detail on the structure of the defense budget and the objectives that will be achieved in attracting active and reserve personnel, the status of the military, and force modernization.

Canada recognizes that, internationally, its forces will conduct operations across the whole spectrum of conflict, but will normally be part of a coalition or alliance. The Canadian Armed Forces lack the capability to achieve international goals by themselves; hence, they could not conduct or even take the lead role in operations on the scale of the Kosovo campaign in 1999. Instead, Canada's ambition is to provide "tacti-

23 Defense White Paper, Delivering Security in a Changing World, volume I (London: Presented to Parliament by the Secretary of State for Defence, December 2003); available at www.mod.uk/linked_files/publications/whitepaper2003/volume1.pdf.

24 2003-2008 Military Program, Bill of Law, France, Unofficial translation (2002), 4-5; available at www.info-france-usa.org/atoz/mindefa.pdf. 
cally self-sufficient units" (TSSU), capable of integrating into combined force packages. The minimum requirement of TSSUs is to be able to conduct at least "medium intensity operations." 25

Sweden's international defense ambition is to be able

... to lead and participate in two large-scale international missions, each requiring the deployment of an entire battalion, and three smaller operations. It shall be possible to undertake some operations with little prior warning and to sustain other operations over a longer period of time. The Swedish Armed Forces shall be able successfully to tackle any crisis management task given to them, from confidencebuilding, conflict prevention, humanitarian and peace-keeping tasks to peace-enforcement measures. ${ }^{26}$

In its 1999 Military Doctrine, Bulgaria clearly stated the defense ambition of the country. At that time, Bulgaria had announced its intentions to seek NATO membership, but accession did not appear to be in the near future. Without the protection of NATO's Article V guarantees, and with the nearby Kosovo crisis still in its "hot" phase, Bulgarian policy makers admitted the possibility for aggression against the country. The stated ambition was to be able to defend the nation's territory and population on its own, without outside assistance. Importantly, the Military Doctrine - a public document approved by the Parliament - described the parameters of the plausible aggression: in one theatre of operations, with significant warning times, and without full mobilization of the aggressor. ${ }^{27}$

\section{Amendment 2: Forces and Capabilities. Linking Defense Objectives and Capabilities}

In designing a defense policy, it is not the forces as such that are important, but rather the capabilities they have, or will have, in relation to the nation's defense objectives (see Figure 3). Furthermore, although most of the nation's defense capabilities are provided by formations of the armed forces (marked on Figure 3 with ' $F$ '), there are cases when requisite capabilities will be provided by other organizations, e.g., non-military intelligence services, police, shipping companies, civilian air transport, etc.

${ }^{25}$ Capability Based Planning for the Department of National Defence and the Canadian Forces (Ottawa: Department of National Defence, May 2002), 14-15; available at www.vcds.forces.gc.ca/dgsp/00native/rep-pub/j-cbpManualPdf_e.asp.

Our Future Defence: The focus of Swedish defence policy 2005-2007, Swedish Government Bill 2004/05:5, 14, emphasis added; available at www.sweden.gov.se/content/1/c6/03/ 21/19/224a4b3c.pdf.

27 Military Doctrine of the Republic of Bulgaria, Approved by the Parliament in 1999, amended in 2002; available at www.mod.bg/en/doc_konc.html\#. 


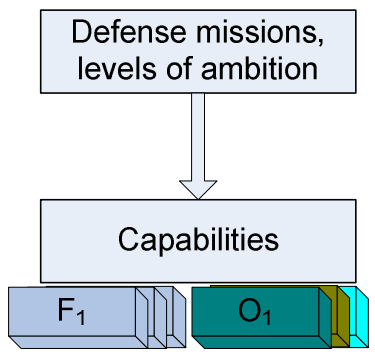

Figure 3: Capabilities as 'Means' in Defense Policy

Capability is defined here as the capacity, provided by a set of resources and abilities, to achieve a measurable result in performing a task under specified conditions and to specific performance standards. ${ }^{28}$ Therefore, the link between objectives and capabilities is not straightforward. The definition of capabilities necessary to achieve the objectives depends on the situations, or scenarios, in which the armed forces might be used, and accounts for the way in which they will be used (see Figure 4).

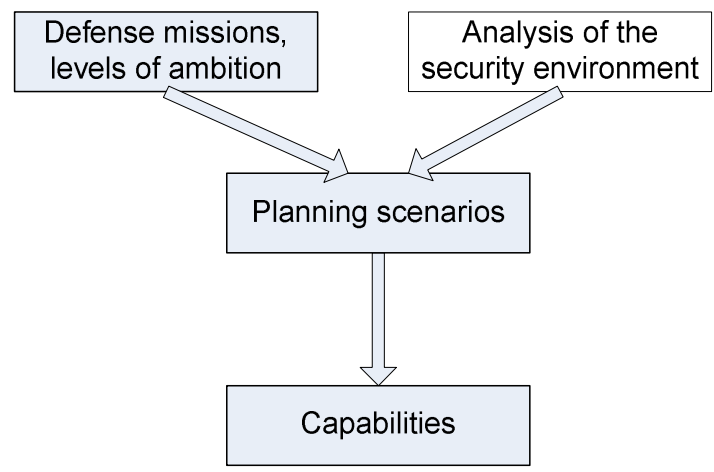

Figure 4: Linking Objectives and Capabilities through Planning Scenarios

\section{Planning Scenarios}

In defense policy-making and planning, scenarios are used as planning situations, specified in terms of environmental and operational parameters. Planning scenarios are not intended to predict future situations and outcomes; rather, they are used in a proc-

28 For alternative definitions, see my accompanying article in this volume. 
ess of specifying force structure and defense plans. They serve several purposes. ${ }^{29}$ First, scenarios broadly describe potential missions, based on challenges or threats faced in a ten to twenty-year time-frame - a duration comparable with the time needed to reshape force structures and develop and field corresponding weapon systems. Second, scenarios lay out assumptions related to the scope of a nation's aims and ambitions $v i s-\grave{a}$-vis its potential challenges and threats. Third, planners use them as a tool to define capabilities to conduct operations and as a testbed for assessing proposed operational concepts, capabilities, or system requirements against formulated mission objectives.

Policy makers and planners need to consider multiple scenarios in order to address the complex nature of military missions and to select a set of scenarios that will be used to shape force development. The set should be representative of the security challenges outlined in the nation's defense policy. The selected scenarios, in combination, need to capture the full spectrum of missions, operations, and objectives and interests of the state. Finally, all selected scenarios must be sufficiently credible so that the resulting analyses and plans will be acceptable. ${ }^{30}$

In its defense policy and planning process, NATO develops nearly thirty generic defense-planning scenarios, ranging from an operation for non-combatant evacuation to forcible entry to major war, which are then used to inventory the capabilities required. ${ }^{31}$ In its proposal for a White Paper on European defense, the group of authors proposed five strategic scenarios: ${ }^{32}$

1. Large-scale peace support operation

2. High-intensity humanitarian operation

3. Regional warfare in the defense of strategic European interests

4. Prevention of an attack involving weapons of mass destruction (WMD)

5. Homeland defense

To take a national example, Canada uses the following set of generic scenarios: ${ }^{33}$

1. Search and rescue in Canada

${ }^{29}$ For details see European Defence: A proposal for a White Paper, Report of an independent Task Force (Paris: EU Institute for Security Studies, May 2004), 67-70; available at www.iss-eu.org/chaillot/wp2004.pdf; and Handbook on Long-Term Defence Planning, RTO Technical Report 69 (Paris: NATO Research and Technology Organization, April 2003); available at http://www.rta.nato.int/Pubs/RDP.asp?RDP=RTO-TR-069.

30 Scenario selection is a critical activity. The need for detail and a broad spectrum of planning scenarios is inevitably confounded by the limited analytical ability of policy makers and planners.

31 Michèle A. Flournoy, "Defense Integration in Europe," notes to slide \# 17.

32 European Defence: A proposal for a White Paper, 71-98.

33 Descriptions-Departmental Force Planning Scenarios (Canada: Department of National Defence, May 2005); available at www.vcds.forces.gc.ca/dgsp/pubs/rep-pub/dda/scen/ intro_e.asp. 


\section{Disaster relief in Canada}

3. International humanitarian assistance

4. Surveillance/control of Canadian territory and approaches

5. Evacuation of Canadians overseas

6. Peace support operations (Peacekeeping)

7. Aid of the civil power/Assistance to law enforcement agencies

7a. Chemical Weapon Variant

8. National sovereignty/interests enforcement

9. Peace support operations (Peace enforcement)

9a. Failed State Variant

10. Defense of North America

10a. Radiological Weapon Variant

10b. Cyber Attack Variant

\section{Collective Defense}

In summary, scenarios are used to describe operational considerations and to rationalize capability requirements.

\section{Nature of Operations}

The definition of the capabilities necessary to achieve the objectives accounts for the way in which these capabilities would be used. That requires an understanding of the changing nature of operations and the potential use of novel operational concepts, e.g., of effects-based operations, network-based warfare, etc. ${ }^{34}$

\section{Missions to Tasks to Capabilities}

Capability is broadly defined as the ability to perform a particular task. ${ }^{35}$ Therefore, planning scenarios are used to derive the set of tasks to be performed in operations. In order to be uniformly understood, each task to be performed in a scenario is defined by the respective term in a generic task list (which is represented in Figure 5).

34 For a comparative analysis of twentieth- and twenty-first-century operations, the reader may refer to Scott Jasper, "Defense Transformation: Required Capabilities for the Future Security Environment," Presentation to the International Defense Transformation Course (Monterey, CA: CCMR, NPS, December 2005).

35 See, for example, Guide to Capability-Based Planning, TR-JSA-TP3-2-2004 (The Technical Cooperation Program, Joint Systems and Analysis Group, Technical Panel 3, MORS Workshop, October 2004); available at www.mors.org/meetings/cbp/read/TP-3_CBP.pdf. 


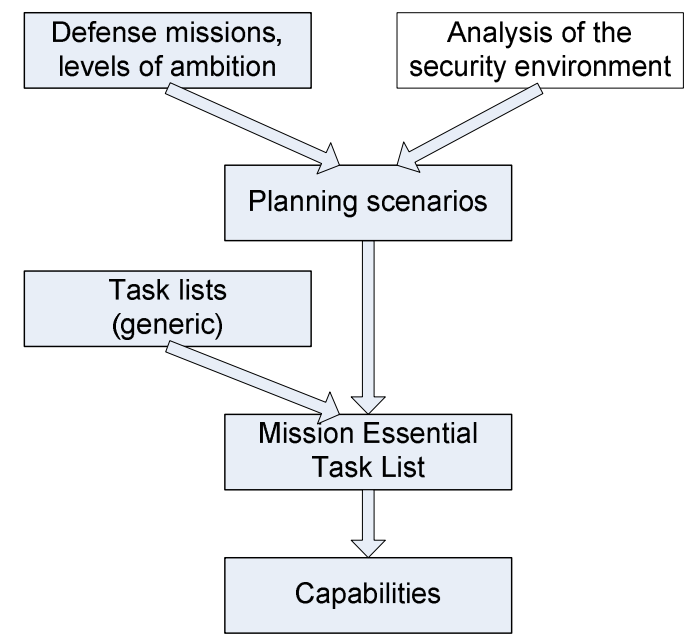

Figure 5: Mapping Capabilities to Tasks

For example, Canadian defense policy-makers and planners use, among other documents, the "Canadian Joint Task List" as a "common lexicon ... for capability planning., 36

In the case of the United States' force planning system, the set of tasks that results from analyzing the scenario set for each mission is referred to as the "Mission Essential Task List." Actually, the tasks can not be defined outside of an explicit concept for employment of the armed forces, or "Operational Concept." Considerable importance in current transformation initiatives is attributed to "Effect-Based Operations" as a driving operational concept. In this approach, capabilities are mapped to desired effects, which are then in turn mapped to operational objectives.

Mission-essential task lists define the types of capabilities needed to accomplish the tasks (or to achieve the desired effects). Then, planners define the capability levels needed to accomplish the tasks (or "capability goals"). Thus, for each scenario, planners design a force package that would provide the capabilities to apply the operational concept and to achieve the mission objectives. The output of the process, presented in Figure 5, is a set of force packages for each scenario. These are then built into a force structure that would allow the military to realize the level of its defense ambitions-

36 Capability Based Planning for the Department of National Defence and the Canadian Forces (Ottawa: Department of National Defence, May 2002), 19; available at www.vcds.forces.gc.ca/dgsp/00native/rep-pub/j-cbpManualPdf_e.asp. 
concurrent participation in operations with a certain duration. ${ }^{37}$ In capability-based planning, the goal is not to optimize the set of capabilities (capability levels or related force package) for a particular scenario; rather, the capability set should be robust as defined against the set of plausible scenarios.

\section{Distribution of Capabilities Among Organizations}

The next task in making security and defense policy is to distribute the requisite capabilities among organizations within a nation's security and defense establishment. Effectiveness and efficiency are important considerations in deciding which capabilities to assign to an organization, and may lead to decisions for the specialization of security sector organizations.

For example, an aerial surveillance and reconnaissance capability, maintained by an air force, may potentially be used in law enforcement efforts (e.g., border control) and disaster management operations. Rather than each organization developing its own aerial surveillance capabilities, a cost-effective solution, particularly for a small country, would be to maintain this capability only in the air force, and to make it available for other types of operations when necessary. Certainly, this will place higher resource demands on the air force, but overall it will be cheaper than the case of three organizations developing and maintaining separate capabilities for aerial surveillance and reconnaissance.

A number of factors, however, such as constitutional arrangements, constrain the scope of possible decisions in this area. In addition, decisions on the distribution of capabilities are influenced by strategy, available experience, perceptions within the military, and, last but not least, resource constraints. Finally, any decision on the specialization of the armed forces needs to be reflected in definitions of their roles and missions.

\section{Amendment 3: Reconciling Objectives, Force Structure, and Financial Constraints - The Role of Planning Risks}

The rule in policy-making is that demands always exceed resource availability. Policymakers and planners work hard to balance goals, strategy, and means, with risk being the balancing factor (see Figure 6). ${ }^{38}$

37 For further considerations and a thorough examination, the reader may refer to the Handbook on Long-Term Defence Planning, RTO Technical Report 69 (Paris: NATO Research and Technology Organization, April 2003), 9-15; available at http://www.rta.nato.int/Pubs/ RDP.asp?RDP=RTO-TR-069.

38 This is an adaptation of the "Bartlett model" of strategy development, presented in Bartlett, Holman, and Somes, "The Art of Strategy and Force Planning," 15-27. 


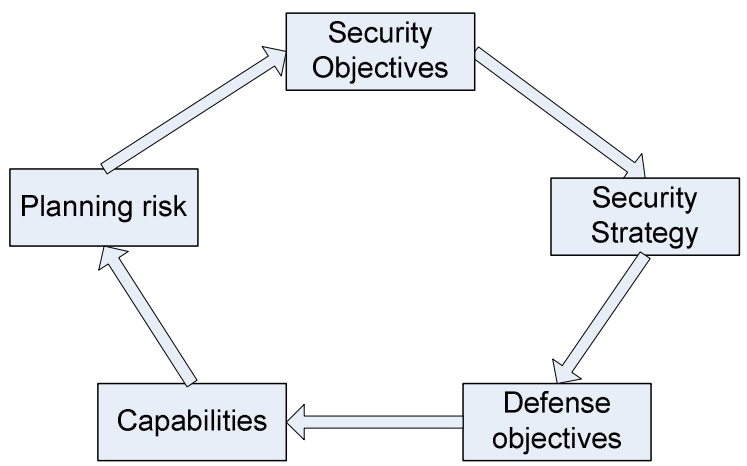

Figure 6: General Policy-making Cycle

Realistically, policy-makers recognize that all the main variables-objectives, strategy, means, and risk - need to be treated as variables until a good balance is found. Obviously, the search for a balanced policy is sought in the current and anticipated security environment and within resource constraints (as represented in Figure 7).

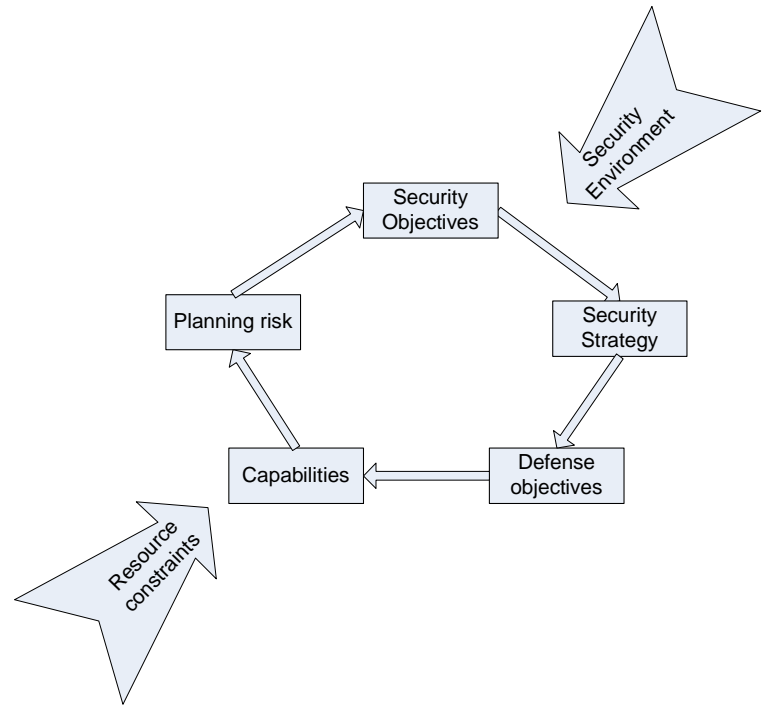

Figure 7: Policy-making Cycle in a Context

Hence, a realistic defense policy is based on the recognition that it is not possible to guarantee a nation's security against all possible threats. Instead, it is based on a risk 
management approach. Policy-makers and planners distinguish four related types of risks: ${ }^{39}$

- Operational risks, associated with the current force structure that, if deployed, will execute the strategy successfully within acceptable human, material, financial, and strategic cost.

- Defense planning, or future challenges risks, associated with future capacity to execute missions successfully against a spectrum of prospective future challenges.

- Implementation, or force management risks, associated with the successful implementation of force structure decisions and force development plans. The primary concern here is recruiting, training, and retaining military and civilian personnel, equipping the force, and sustaining an adequate level of readiness.

- Institutional risks, associated with the capacity of new command, management, and business practices.

The second category of risk is of primary importance in making defense planning decisions and, thus, in designing defense policy.

Defense planning risk is measured through the impact or consequence of an unfavorable outcome, given the occurrence of some military event or other event of organized violence, and a nation's force structure. Thus, the measure of risk is probabilistic. It is defined by the likelihood of the occurrence of an event and the estimated consequences in case the event occurs and we have a given force structure in place.

Each force structure is associated with a certain level of risks. Figure 8 presents visually the difference between two force structures under examination. Force Structure $_{1}$ is associated with Risk ${ }_{1}$, and could be built and sustained if Budget ${ }_{1}$ is made available. When a given force structure is defined as needed, defense planers (often implicitly) assume that the associated risk, i.e., Risk ${ }_{1}$, is acceptable. When planners have to find a force structure that is "realistic"-i.e., that could be built and sustained within expected budgets (Budget ${ }_{2}$ in the figure) - they create plans for a force structure associated with Risk .

In practice, the mismatch between needs, or the required defense capabilities, and resource constraints is inevitable. It creates a gap of unfunded capabilities. What could be done in regard to that gap? Dr. Jack Treddenick, Professor at the College of International Security Studies at the George C. Marshall Center in Garmisch-Partenkirchen, Germany, has identified a number of possibilities: ${ }^{40}$

- Pretend the gap does not exist

39 The National Defense Strategy of the United States of America, 11. U.S. defense strategy defines (1) operational, (2) future challenges, (3) force management, and (4) institutional risks.

40 Jack Treddenick, "Transparency and Efficiency in Defense Planning and Spending," Presentation to the PfP Consortium Security Sector Reform Conference (Garmisch-Partenkirchen: George C. Marshall Center, 13 December 2005). 


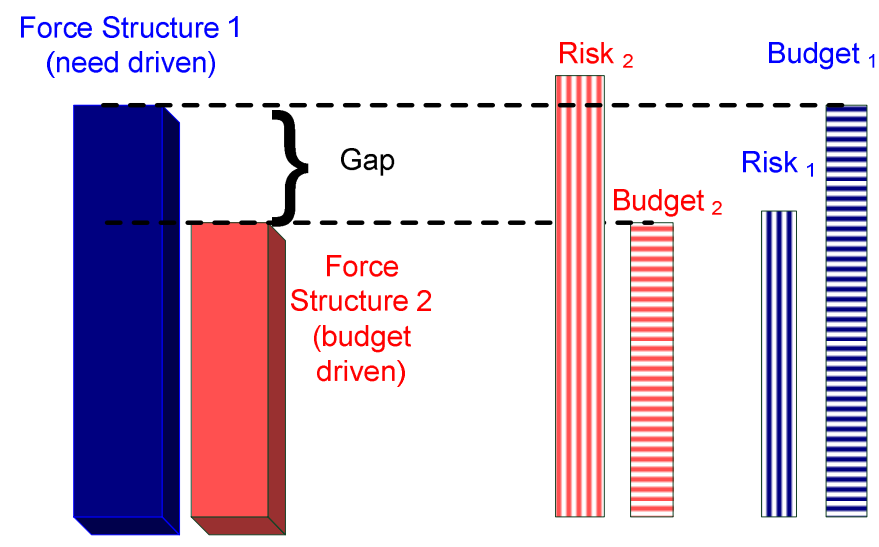

Figure 8: Force Structures, Risk Levels and Budgets

- Revisit the national security strategy

- Revisit the national military strategy

- Revisit the required force structure

- Reconsider the allocation of resources to defense

- Seek improvements in efficiency

- Transform the armed forces

Thus, one opportunity is to seek a better force structure within Budget ${ }_{2}-\mathrm{a}$ different set of capabilities and more efficient and effective use of resources - so as to lower the associated Risk ${ }_{2}$. That is not always possible. Another opportunity is to reconsider the ways in which the armed forces operate. A third option is to reassess the nation's security strategies: seek entry into an alliance, enhance security cooperation, apply confidence-building measures with neighbors, etc. The fourth option is to provide more money for defense spending, which would allow the nation to increase the size and/or the readiness of the armed forces. The fifth option is to decide to reconsider the nation's security objectives and ambition levels. Finally, if all other opportunities are exhausted, we may have to accept the level of risk associated with the planned force structure.

Usually, a proposal for a force structure may be accepted if the associated planning risk is acceptable (i.e., the likelihood of an event's occurrence is determined to be low) or the likely consequences, given such an occurrence, are judged to be minor. An analysis of past experience, simulations, and expert judgment are used to assess risk. Whatever the approach, in the end the acceptance (or non-acceptance) of a planning risk strongly depends on the personality of the decision-maker. Some people are riskaverse, while others are more wiling to accept risk. Thus, any risk management strategy is inherently subjective. 
On the whole, risk assessment should be integrated into the process of making decisions and setting priorities among competing demands. A fairly self-explanatory risk management model is presented in Figure $9 .^{41}$ Risk assessments, among other things, may be used to assign risk management responsibilities along organizational hierarchies.

\section{Estimated negative impact}

\begin{tabular}{|c|c|c|c|}
\hline Significant & $\begin{array}{c}\text { Considerable } \\
\text { management } \\
\text { required }\end{array}$ & $\begin{array}{c}\text { Must manage } \\
\text { and monitor risks }\end{array}$ & $\begin{array}{c}\text { Extensive } \\
\text { management } \\
\text { essential }\end{array}$ \\
\hline Moderate & $\begin{array}{c}\text { Risk may be worth } \\
\text { accepting with } \\
\text { monitoring }\end{array}$ & $\begin{array}{c}\text { Management } \\
\text { effort worthwhile }\end{array}$ & $\begin{array}{c}\text { Management } \\
\text { effort required }\end{array}$ \\
\hline Minor & Accept risks & $\begin{array}{c}\text { Accept, but } \\
\text { monitor risks }\end{array}$ & $\begin{array}{c}\text { Manage and } \\
\text { monitor risks }\end{array}$ \\
\cline { 1 - 3 } & Low & Medium & High \\
& Likelihood &
\end{tabular}

Figure 9: A Basic Risk Management Model

\section{Summary}

There is no computer-applied algorithm for the application of a scenario-led, capability-based approach to force planning. Nevertheless, effective defense policies are based on disciplined approaches to the creation of force structure and force development plans that share some common steps:

- Definition of defense objectives, missions, and ambitions

- Design of and agreement on plausible scenarios, or environments in which these missions will be carried out (often including development of adequate operational concepts and selection of a course of action)

41 Adapted from Integrated Strategic Risk Management (ISRM) in Defence (Ottawa: Department of National Defence, 2003), available at www.vcds.forces.gc.ca/dgsp/pubs/rep-pub/ $\mathrm{dda} /$ cosstrat/isrm/intro_e.asp. 
- Deconstruction of scenario activities into tasks and definition of "mission-essential task lists" (tasks are often drawn from generic task lists)

- Definition of the capabilities needed to accomplish the tasks; this step includes a number of sub-steps, the latter two performed in iteration:

o Definition of the needed types of capabilities

o Assessment of the planning risks

o Design of a cost-effective force package that would provide capability levels needed to accomplish the tasks with acceptable risk

- Design a force structure appropriate for all anticipated missions and scenarios

All these steps may be performed in a variety of ways. What is important is to adhere to a rational, disciplined approach to defense policy-making and the principles of transparency and accountability. The examples from the experiences of democratic societies with mature defense policy-making mechanisms presented in this article may help PfP member states who endeavor to effectively manage the development of their armed forces. 


\section{Bibliography}

Bartlett, Henry, Paul Holman, and Timothy E. Somes. "The Art of Strategy and Force Planning." Strategy and Force Planning (2004): 17-33.

Capability Based Planning for the Department of National Defence and the Canadian Forces . Canada: Department of National Defence, 2002.

Delivering Security in a Changing World. Vol. 1. Defence White Paper 1., 2004.

Department of Defense Dictionary of Military and Associated Terms. Washington, D.C.: Department of Defense, 2008.

Descriptions - Departmental Force Planning Scenarios . Canada: Department of National Defence, 2005.

European Defense: A Proposal for a White Paper In Report of an independent Task Force. Paris: EU Institute for Security Studies, 2004.

Flournoy, Michèle A.. Defense Integration in Europe: Enhancing Europe's Defense Capabilities for New Missions In Clingendael Security and Conflict Programme workshop "Enhancing European Military Capabilities within the EU and NATO,". The Hague, 2005.

Handbook on Long Term Defence Planning In RTO Technical Report 69 . Paris: NATO Research and Technology Organisation, 2003.

Jasper, Scott. "Defense Transformation: Required Capabilities for the Future Security Environment." In International Defense Transformation Course. Monterey, CA: CCMR, NPS, 2005.

Military Doctrine of the Republic of Bulgaria. National Assembly, 1999.

NATO Glossary of Terms and Definitions In NATO Standarization Agreement AAP-6., 2008.

Nelson, Daniel. "Beyond Defense Planning." Connections: The Quarterly Journal 1, no. 2 (2002): 101-111.

Our Future Defence: The Focus of Swedish Defence Policy 2005-2007., 2005.

Program, The Technical. Guide to Capability-Based Planning. Alexandria, VA: The Technical Cooperation Program, 2004.

Simon, Jeffrey. "The New NATO Members: Will They Contribute?" In Strategic Forum 160 . Washington, D.C.: National Defense University, 1999.

South East Europe Common Assessment Paper on Regional Security Challenges and Oppor-tunities - SEECAP. Budapest, 2001.

The National Defense Strategy of the United States of America . Washington, D.C.: Department of Defense, 2005. 
THE QUARTERLY JOURNAL

The National Security Strategy of the United States of America., 2002.

Treddenick, Jack. Transparency and Efficiency in Defence Planning and Spending In PfP Consortium Security Sector Reform Conference. Garmisch-Partenkirchen, 2005.

Webster's Ninth New Collegiate Dictionary . Springfield, Mass.: Merriam Webster Inc, 1991.

White Paper on Defence . Canadian Department of National Defence, 1964. 